\title{
LIBRARY MANAGEMENT ANALYSIS TO IMPROVE THE QUALITY OF EDUCATION IN JUNIOR HIGH SCHOOL IN SANGGALANGI' SUB- DISTRICT, NORTH TORAJA REGENCY
}

\author{
Desty Pali Saludung ${ }^{1}$, Mesta Limbong ${ }^{1}$ and Hotmaulina Sihotang ${ }^{1}$ \\ ${ }^{1}$ Program Pacasarjana, Universitas Kristen Indonesia (UKI), Jakarta, Indonesia
}

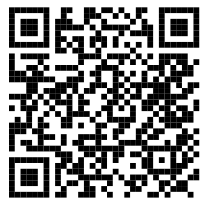

Received 3 April 2021

Accepted 18 April 2021

Published 30 April 2021

Corresponding Author

Desty Pali Saludung, destypalisalu

dung@gmail.com

DOI 10.29121/

granthaalayah.v9.i4.2021.3892

Funding: This research received no specific grant from any funding agency in the public, commercial, or not-for-profit sectors.

Copyright: (C) 2021 The Author(s). This is an open access article distributed under the terms of the Creative Commons Attribution License, which permits unrestricted use, distribution, and reproduction in any medium, provided the original author and source are credited.

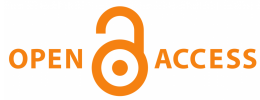

\section{ABSTRACT}

This research aims to know the function of library management to improve the quality of education in junior high schools in Sanggalangi Subdistrict, North Toraja Regency. The method used in this study is the qualitative approach method. In qualitative approaches, the primary data collection tool is a researcher who acts as a full observer of things that concern the management of libraries relating to the quality of education. The data was obtained through observations, interviews, and documentation directly at junior high school in Sanggalangi Subdistrict, North Toraja Regency. Resource persons in this study are principals, librarians, teachers, and supervisors of junior high school in Sanggalangi Subdistrict. Data validation by triangulation is source triangulation, technique and time. The results showed that library management in junior high school in Sanggalangi Subdistrict, North Toraja Regency, in general, has shown good things but experienced various obstacles in the field both in terms of infrastructure and from the library staff where the librarians do not have library background. The quality of junior high school education in Sanggalangi Subdistrict, North Toraja Regency, is still limited due to limited human resources and facilities that are not optimal, but in some schools, it has improved. It can be seen that there are students in Sanggalangi Subdistrict who have achievements. The use of the library is very influential on the quality of education because through the library, teachers and students can obtain the knowledge and information needed in the learning process.

Keywords: Library Management, Quality of Education

\section{INTRODUCTION}

Education is one of the essential components in the formation of the human person. A country that can thrive if it is filled and controlled by skilled people and have good character. In other words, human resources are the determinants of a 
nation's progress. Realizing it, the government seeks to improve the quality of education because a sound education system is expected to emerge the next generation of qualified people and make changes in the direction of the nation's life and statesociety Beeby (2013); Tikly and Barrett (2011). The achievements obtained by the students are the result of the interaction of various factors. Factors that affect it include internal factors such as intelligence, interests, talents, motivations and external factors consisting of family environment, learning environment, and community environment Arnone et al. (2011); Tikly and Barrett (2011).

A child said to be successful or not in education depending on the learning process experienced by the child. Learning achievement is a measurement in the learning process in the form of numbers or passions that reflect the mastery of the lesson material for students. Learning achievements are learning outcomes achieved by students with predetermined criteria. As a source of information, school libraries must present the correct information to their users because the right information will make crucial decisions in their lives Kuhlthau (2010); Small et al. (2010). If students already have experience in applying information skills using the school library, they will live independently. School libraries need to be managed well in library management to provide the correct information for their users. Library management needs to be based on the theory and management principles called library management. Library management is a process or framework that involves guidance or direction in library activities and has a specific purpose. Management is an instrument to optimize the functioning of components of a system in a planned, organized, directed, coordinated, controlled and evaluated Nadeak and Naibaho (2020).

However, in reality, not all schools can organize a school library properly. There are still many obstacles faced by schools, one of which is the lack of knowledge of library managers about library management issues. The books about the school library in circulation primarily discuss technical matters about the organization of the library and not the management of the library itself Hay and Foley (2009); Subramaniam et al. (2012). Currently, the problem is why the library has not served as an actual medium of information. This issue often causes library users to run elsewhere to get the information they want. School library management is the process of optimizing human contributions, materials, budgets to achieve library goals. Then in another sense, it is mentioned that library management is the process of library management based on the principles and theories of management Thomas et al. (2020).

The management of existing school libraries optimizes human contributions, materials, and budgets to achieve library goals. Then in another sense, it is mentioned that library management is the process of library management based on the principles and theories of management. In essence, management is an activity to achieve goals through the work of others Nadeak et al. (2021); Sihotang and Nadeak (2017). In more detail, it can be stated that management includes the design and business properties of the group to achieve the objectives, but with the use of capital in the form of time, money, materials, and obstacles encountered, to a 
minimum. In other words, the basic concept of management is planning, organizing, implementing and controlling an activity that aims to allocate resources so that it has added value Rahman et al. (2020).

Sanggalangi' subdistrict is a subdistrict very close to the centre of North Toraja regency. Access to Sanggalangi' subdistrict is adequate and continues to increase, but the rapid development has not been accompanied to the maximum in improving the quality of education, specifically at the junior high school level. Where all these schools can be reached easily but in general have not shown maximum achievement. The condition of the libraries in these three schools is still far from standard, which is managed roughly, and there is no exceptional professional staff in the field of libraries that contain Reed (1971); Rubin (2017).

In principle, students have a great animo towards the library's existence as a means to gain more knowledge but still constrained in the availability of books they need. So they look for other solutions through gadgets or even undo their intention to seek information. From the above phenomenon where students' learning achievement is still meagre, which shows the low quality of education, researchers are interested in studying more about the impact of complete library management on improving the quality of teaching and choose the title "Library Management Analysis on The Quality of Education in Junior High School in Sanggalangi Subdistrict' North Toraja Regency.

Quality - "The meaning of product quality is closely related to the level of perfection, conformity with needs, free from defects, free from imperfections, or free from contamination and the ability to satisfy consumers" Nadeak et al. (2019). Consumers are the most appropriate and fair party in assessing the quality issues of the products provided. "There are eight quality dimensions that can be used to analyze the quality characteristics of goods, namely as follows: a) Performance, related to the functional aspects of the product and is the main characteristic that customers consider when wanting to buy a product. For example, the performance of car products is speed, comfort, and maintenance; b) Features is the second aspect that adds essential functions related to choices and development. For example, the features for car products are roofs that can be opened. Features are additional or complementary features or features; c) Reliability, "relating to the possibility of a product functioning successfully within a certain period under certain conditions. For example, the reliability of a car is speed; d) Conformance, relating to the level of conformity of the product to the predetermined specifications based on the customer's wishes; e) Durability is a measure of the life of a product. This characteristic relates to the durability of that product; f) Serviceability is a characteristic related to dexterity/decency, competence, ease, and improvement; g) Aesthetics is a subjective, subjective, subjective, related to personal considerations and reflections of individual preferences or thoughts; and h) Perceived quality, subjective, related to the customer's feelings in consumer products, such as increasing self-esteem Al-Debei and Avison (2010); Gentile et al. (2007); Safiullin et al. (2012); Todinov (2015). 
Library Management - Library comes from the word liber = Libri means "library" or book". Based on PP No. 24 of 2014 on the implementation of Law No. 43 of 2007, "the library is an institution that manages the collection of writings, printed works, and/or record results professionally. It is organized with a standard system to meet the needs of education, research, preservation, information, and recreation of the musicians. This definition makes a guideline for conducting library activities as a unit of information providers for the community and its musicians. "In the library, there are many aspects that need to be considered to create a library purpose, ranging from the availability of collections, classification to spatial planning Barrett (2010); Gildersleeves (2012); Xie and Matusiak (2016).

Management is a comprehensive component that cannot be separated from the educational process as a whole Limbong (2017); Naibaho and Silalahi (2020). Management leads us to educational objectives that can be realized optimally, effectively and efficiently. Thus comes awareness of the importance of School-Based Management (SBM), which gives full authority to schools and teachers in regulating education and teaching and decision making.

Library Services - "Special services or assistance services are held to facilitate the implementation of teaching to achieve educational goals in schools." One of them is the school library service is to provide exceptional services to students, and hopefully, all school residents can feel the various services offered by the school Breyer et al. (2020).

\section{RESEARCH METHOD}

The method used by the authors in this study is the qualitative research method. In qualitative research, the primary data collection tool is researchers. In this study, researchers acted as total observers. Namely, researchers closely observe things related to library management concerning the quality of education. The data was obtained through observations, interviews, and documentation directly at the research site, namely junior high school in Sanggalangi Subdistrict, North Toraja Regency. The speakers in this study consisted of principals, librarians, teachers, and junior high school supervisors in Sanggalangi Subdistrict. Data validation using triangulation, i.e. source triangulation, technique and time."

\section{RESEARCH RESULTS}

This research focuses on library management's function concerning the quality of education in junior high school in Sanggalangi Kabuaten North Toraja Subdistrict. It is described in the sub-focus of how library management is planning, organizing, actuating and controlling, how the quality of education and how the impact of library management on the quality of education in junior high school in Sanggalangi' Kabuaten District of North Toraja. 
Library Management Functions at Smp in Sanggalangi' Subdistrict - School library management is an activity or activity of library management that is part of a school educational institution with learning resources systematically conducted through planning, organizing, leadership, and supervision directed and able to provide convenience for students in developing science and reading interests. Effective and efficient library management will meet students' needs for science, increase reading interest in students, and improve the quality of education in schools.

Planning - Based on the results of interviews with several principals, it appears that the school, in general, has programmed the procurement of books in schools, such as the opinion of YP, who said that the school plans library budgets in the Bos Fund RKAS and prepare funds for the implementation of library programs.

The involvement of all parties in library management planning is highly expected. So that everyone understands everything in library management. As the result of an interview with LLA as one of the library personnel who suggested that in the planning of library management, the thing to do is to propose additional books, both student package books and other reference books, propose a wardrobe of texts as needed, the preparation of library programs following the development of the curriculum. It indicates that library personnel are also involved in library planning because they know more about improving library services.

Related to the Planning Facilities and Infrastructure Library mechanism, then based on the results of interviews with ASL, which is done in schools in library implementation. It is done to plan the needs of library facilities and infrastructure through meetings with the board of teachers, education officials, and school committees, budgeting the needs of library facilities and infrastructure in the program RKAS Dana Bos, realizing the program of library facilities and infrastructure as needed. Based on the interview results, the role of the school in maximizing the use of libraries to support the improvement of the quality of education is enormous and needs serious handling. Management strategies need to be improved to produce good quality.

Based on the observations in the field, the condition of the library in junior high school in Sanggalangi Subdistrict, North Toraja Regency, is not all adequate for educational needs. Based on the results of an interview with VNB, the school does not yet have a library building, where the library space used today is a classroom that is still empty and unused. The area used by this temporary library contains a book cabinet or, most precisely, a bookshelf of 5 (five) pieces with a width of 2 meters and a height of 1.5 meters provided by the school from self-cost, a 4-piece long chair and a 4-piece long table. The means of bookshelves, chairs, tables and rooms are in good condition. The books available in student package books, teacher handbooks, reference books, and reading books are minimal.

But the different things conveyed by LLA that the building is in good condition, the library room has a reading room, and the book room is in good condition, the library books are arranged with rap. It shows that the library state in junior high school in Sanggalangi Subdistrict, North Toraja Regency, is not all adequate, so it certainly 
needs attention from all parties concerned. But the good thing is that the condition of all libraries is well laid out and neatly following the state of existing infrastructure facilities. The collection of books in the library is undoubtedly a problem in the library. It is due to the need for books for all students quite often, while the curriculum often applied changes. In addition to textbooks, of course, a collection of general knowledge is needed as literature.

Organizing - Related to the organization in the library in junior high school in Sanggalangi' North Toraja area, it can be seen from interviews with several informants. The mechanism taken by the teacher in using the library is associated with the completed learning program, such as the OT's opinion. How to arrange for students to use the library is that students are allowed to use the library starting at 7.30 am, especially for the class leader who is in charge of taking the student package book in the library several needed in the classroom and then returning the package book when the lesson is finished. The library can also be used by students whose teachers are not in the school so that the picket teacher directs the class to read in the library if the teacher gives no assignment. But sometimes, this learning program encountered obstacles that library officers are not backgrounded in library education, so they do not understand the ins and outs of the library so that officers are less able to capture students' wishes when providing reference services. The same thing was conveyed by $\mathrm{pl}$ that the library service system in schools is still straightforward, librarians have not been maximized in service tasks because the library facilities are also incomplete and sometimes students come to pick up books and write them on loan books without any supervising officers.

EMP experiences different conditions that the service system in our schools makes it easy to find and choose the collection of books needed because there are library managers on duty and carry out library services well. Similarly, al said that the service system in our school is straightforward for us to find and have the collection needed. The conditions in every junior high school in Sanggalangi' North Toraja region in library management are still not uniform from the interview results above. It is because the management system that applies is still following the conditions of each school. There are schools whose library management is good, but there are still those who still need special care.

Actuating - Mobilization is a series of activities carried out according to the plan to achieve specific goals effectively and efficiently. The function is a merger of several management functions interconnected, namely leadership, direction, communication, motivation, and the provision of facilities or facilities. The obstacles faced in library management are package books and reference books that are still not enough. The library room is still used as a study room for Catholic students because it lacks space, so it is less effective in managing the library, which should be a comfortable room for reading. Similar obstacles posed by VNB that the challenges faced by the library are package books and reference books that are still lacking. The school also does not have a particular library building as well as other library facilities. Librari- 
ans.

The use of the library as an information knowledge source continues to be encouraged, such as the opinion of HR. The steps taken to promote the utilization of libraries in schools are the socialization of literacy culture for students and teachers, to conduct literacy activities by utilizing reading books from the library, socialization of reading activities for students and teachers so that teachers and students take time to use their free time or free time by reading in the library. It appears that the socialization of library utilization is essential to be rolled out so that all school residents can feel the benefits of the existence of the library.

Controlling - In the supervision of services in the library in junior high school in Sanggalangi Subdistrict' as lla opinion that if there is no library officer who supervises then, of course, the utilization of the library will not be effective because students who study can be noisy in the room and could damage existing goods. Based on the interview results above, nampka, basically applying library management functions in planning, organizing, and mobilization, goes but sometimes not accompanied by reasonable control. It can undoubtedly impact the library's pre-retirement facilities, especially about collecting books that can not match the recorded because sometimes students come to pick up books without any officer taking notes. It certainly goes back to the competence of library personnel who are sometimes negligent in carrying out their duties. It is in line with DPS opinion that the factor that can support the quality of library services is the presence of library personnel who are always on duty and the presence of the head of the library who always controls activities in the library. Further, he suggested that in improving the quality of library services, what needs to be done is to apply discipline for library personnel to be present on time in schools to perform library services at all times. Include library personnel in seminars or training in the field of libraries to be proficient in library management. Conducting performance assessments for library personnel and evaluating their performance to be able to scratch any shortcomings and develop their potential. It appears that the professionalism of library personnel largely determines the supervisory function of library services.

Quality of Education in Junior High School in Sanggalangi' Subdistrict - Sanggalangi subdistrict, located on the outskirts of the district capital, has vast potential in improving the quality of education. Academic and non-academic achievements are achieved from various levels. As the results of interviews with DPS that in the region sanggalangi, achievements earned by students have been immensely proud, wherein each event of the race, existing students can compete with students from schools in the city. They often perform at the district, provincial, and national levels. But of course, this achievement is only achieved by a few people, but in general, there are still many who have minimal competence/knowledge. Similarly, ASL said that many of the alumni in junior high school in sanggalangi' area could get an education at a favourite school in the city. 
From observations in the field, many parents in sanggalangi's area prefer to send their children to school in the city than to send their children to their village. Many considerations are given among them: parents' desire to send their children to schools with more complete facilities. Selin's schooling of children in the city will undoubtedly provide more experience because they can get along with their colleagues from various places. The opinions of some of the teachers interviewed conveyed something in support of this. In the opinion of the OT that the use of libraries is very influential on the quality of education because through the library, teachers and students can get the knowledge information needed in the teaching and learning process. Similarly, emp said that the use of libraries is very influential on the quality of education because through the library, teachers and students can get the knowledge information needed in the teaching and learning process.

From the results of interviews with several teachers as described above, it can be concluded that the use of libraries is vital in supporting the learning process in schools. It is because the library is a place to get information about the learning carried out. But sometimes there are constraints so that the revolution in using the library is not optimal with the limitations of the source of funds and personnel who handle it. According to ASL, the library's impact on the quality of education is that the library provides a means of package books for students, teacher handbooks, and other reference book books. It can be used by students and teachers at any time, making it easier for students and teachers to use the books to find and add the knowledge information needed both in the classroom and at home. Furthermore, it is conveyed that with the facilities of this library facilities, the interest in reading and learning interests of both students and teachers is getting better to enable students' learning outcomes, improving the quality of education in schools.

The impact of library management on the quality of education - Concerning school, library management plays a role in improving the quality of education, and library officials generally realize that a well-managed library will impact the quality of education. Following MT's opinion, school library management plays an essential role in improving the quality of education. Similarly, LLA said that school library management plays a critical role in improving the quality of education. It is conveyed by VNB, who stated that school library management is crucial in improving the quality of education. The conditions in each library will undoubtedly have an impact on the reaction of students in the library. It can be seen from MT's opinion that students feel at home in the library because it is clean and tidy and books are neatly arranged as well. LLA conveyed that students feel at home in the library because the room is clean and tidy, and the books are arranged nicely and neatly. In addition, there is always a library officer who manages the library. However, it is different from what VNB experienced that students only use the library when picking up package books for class use and teachers because of the limited package books and reading books. The room is also limited because it consists of 4 long chairs and four long tables and chairs to read books. It is due to the less likely condition of the room. 
According to AK, the libraries impact the quality of education in North Toraja as a source of knowledge information for students and teachers has no maximum impact on the quality of education in North Toraja. It is due to the lack of management and also library facilities for some schools. Furthermore, he explained that the obstacle factor in using libraries is Android phones that become an instant means for teachers and students to find information. Related to the factors inhibiting the quality of libraries in North Toraja, the problem faced is the lack of library management personnel following educational qualifications, lack of interest in reading students, still lack socialization to school residents about the importance of reading, the library has not been managed with good management. In addition to the field of facilities, activities carried out to improve the quality of libraries such as the availability of library personnel following educational qualifications, Archiving (administration), Library Management (management), committee and government support.

But the condition in the field sometimes the energy placed in the library is rough, regardless of the background. It causes the service in the library to be less maximal. According to the SDP, the library provides books for teachers and students to add insight into the knowledge of teachers and students to overcome learning difficulties for teachers and add references for teachers. Students' learning difficulties can be overcome so that learning outcomes increase. Teacher knowledge also increases so that the teaching and learning process in the classroom can achieve the expected learning objectives. Improved learning outcomes will improve the quality of education in schools.

From the education office, facilitating library programs in schools is essential but has some obstacles. According to HR, in general, a junior high school library in North Toraja has not been fully functioned, both in terms of planning, management, power and infrastructure. Programs conducted in the North Toraja education office in support of libraries in schools include the construction of library rooms and facilities for schools that do not have, pieces of training or seminars for librarians, procurement of package books and other literature. The role of the government as a facilitator of library management in each region should provide support for the existence of libraries. Through the education office, the government is well aware of the condition of the library in the school. So that from the education office facilitated in the form of budgeting, training and other strategies. In addition, library managers must also clearly understand how procedures can be done effectively and reflect the school's needs. The policies referred to herein include funding, management, support for teachers and other related factors.

Service activities and the socialization of library benefits should also be evaluated regularly every year. Promotional activities and library services become the spearhead for the success of the vision and mission of school library management. Because through these two activities all the planning, policies, procedures and management preparations that have been set will be tested for success in supporting the education and learning process in schools" which will ultimately improve the quality of 
education.

\section{CONCLUSION}

The function of library management in junior high school in Sanggalangi Subdistrict, North Toraja Regency, in general, has been good as library management at SMPN 1 Sanggalangi but also experienced various obstacles in the field both in terms of infrastructure and from library personnel such as library management at SMPN 2 Sanggalangi and SMP Rama Tallung Penanian. The quality of junior high school education in Sanggalangi Subdistrict, North Toraja Regency, is still limited in human resources and infrastructure facilities, as it is found at SMP Rama Tallung Penanian. However, at SMPN 1 Sanggalangi and SMPN 2, Sanggalangi Satap has improved. It can be seen that there are students from Sanggalangi sub-district schools who have achievements in various fields. The use of libraries is very influential on the quality of education in junior high schools in Sanggalangi subdistrict because through libraries, teachers and students can get the knowledge information needed in the teaching and learning process.

\section{ACKNOWLEDGEMENT}

The author would like to express his sincere gratitude to Mrs Adolfina Sanda Layuk, S. Pd and Mr Yakob Palino, S. Pd, as the principal who has sincerely taken his time to provide guidance, guidance, input and advice that is very valuable in the preparation of this article.

\section{REFERENCES}

Al-Debei, M. M., \& Avison, D. (2010). Developing a unified framework of the business model concept. European Journal of Information Systems, 19(3), 359-376. Retrieved from https://dx.doi.org/10.1057/ejis.2010.21 10.1057/ejis.2010.21

Arnone, M. P., Small, R. V., Chauncey, S. A., \& McKenna, H. P. (2011). Curiosity, interest and engagement in technology-pervasive learning environments: a new research agenda. Educational Technology Research and Development, 59(2), 181-198. Retrieved from https://dx.doi.org/10.1007/s11423-011-9190-9 10.1007/s11423-011-9190-9

Barrett, L. (2010). Effective school libraries: evidence of impact on student achievement. The School Librarian, 58(3), 136-136.

Beeby, C. E. (2013). he quality of education in developing countries. The quality of education in developing countries.

Breyer, C., Lederer, J., \& Gasteiger-Klicpera, B. (2020). Learning and support assistants in inclusive education: a transnational analysis of assistance services in Europe. European Journal of Special Needs Education, 1-14. Retrieved from https://dx.doi.org/10.1080/ 08856257.2020.1754546 10.1080/08856257.2020.1754546

Gentile, C., Spiller, N., \& Noci, G. (2007). How to sustain the customer experience: An overview of experience components that co-create value with the customer. European management journal, 25(5), 395-410. 
Gildersleeves, L. (2012). Do school libraries make a difference? Some considerations on investigating school library impact in the United Kingdom. Library Management, 33(67), 403-413.

Hay, L., \& Foley, C. (2009). School libraries building capacity for student learning in 21C. Scan, 28(2), 17-26.

Kuhlthau, C. C. (2010). School libraries in the 21st century. Guided inquiry: School libraries in the 21st century, 16, 17-28.

Limbong, M. (2017). THE ROLE OF CORPORATE SOCIAL RESPONSIBILITY IN QUALITY IMPROVEMENT OF 9-YEAR EDUCATION. Journal of Education Research in Administration and Management (JERAM), 1(1), 11-11. Retrieved from https://dx.doi.org/10 .29061/jeram.v1i1.27 10.29061/jeram.v1i1.27

Nadeak, B., \& Naibaho, L. (2020). MOTIVATION AND HRM FACTORS RELATION TO THE EMPLOYEE LOYALTY. Polish Journal of Management Studies, 22(2), 261-276. Retrieved from https://dx.doi.org/10.17512/pjms.2020.22.2.18 10.17512/pjms.2020.22.2.18

Nadeak, B., Naibaho, L., Sunarto, S., Tyas, E. H., \& Sormin, E. (2021). Learning Management in Suburban Schools During the Midst of COVID-19. Psychology and Education Journal, 58(2), 1131-1139.

Nadeak, B., Sasmoko, Simanjuntak, D. R., Naibaho, L., Sormin, E., Juwita, C. P., \& Pardede, S. O. (2019). Analysis of Nursing Quality Services. Indian Journal of Public Health Research \& Development, 10(6), 1380-1380. Retrieved from https://dx.doi.org/10.5958/0976 -5506.2019.01490.6 10.5958/0976-5506.2019.01490.6

Naibaho, L., \& Silalahi, M. (2020). COVID-19 and Students' Anxiety Management. International Journal of Innovation, Creativity and Change, 13(7), 1574-1587.

Rahman, M. A., Santosa, A. B., \& Sihotang, H. (2020). The Influence of Principal's Leadership, Teacher Performance And Internal Quality Assurance System in Improving The Quality of Education in Vocational High School. Kelola: Jurnal Manajemen Pendidikan, 7(2), 162-175.

Reed, S. R. (1971). The curriculum of library schools today. The curriculum of library schools today: a historical overview. Education for Librarianship: The Design of the Curriculum, 19.

Rubin, R. E. (2017). Foundations of library and information science. Foundations of library and information science.

Safiullin, L. N., Gafurov, I. R., Bagautdinova, N. G., \& Safiullin, N. Z. (2012). Influence of quality of the goods on the satisfaction of consumers. GSTF Journal on Business Review (GBR), $2(2)$.

Sihotang, H., \& Nadeak, B. (2017). Leadership Based on the Internal Quality Assurance System in the Christian University of Indonesia. Advances in Social Science, Education and Humanities Research (ASSEHR), 66, 35-43.

Small, R. V., Shanahan, K. A., \& Stasak, M. (2010). The Impact of New York's School Libraries on Student Achievement and Motivation. In The Impact of New York's School Libraries on Student Achievement and Motivation: Phase III (pp. 13-13). School Library Media Research.

Subramaniam, M. M., Ahn, J., Fleischmann, K. R., \& Druin, A. (2012). Reimagining the Role of School Libraries in STEM Education: Creating Hybrid Spaces for Exploration. The Library Quarterly, 82(2), 161-182. Retrieved from https://dx.doi.org/10.1086/ $66457810.1086 / 664578$

Thomas, N. P., Crow, S. R., Henning, J. A., \& Donham, J. (2020). Information Literacy and Information Skills Instruction. Information Literacy and Information Skills Instruction: New 
Directions for School Libraries.

Tikly, L., \& Barrett, A. M. (2011). Social justice, capabilities and the quality of education in low income countries. International Journal of Educational Development, 31(1), 3-14. Retrieved from https://dx.doi.org/10.1016/j.ijedudev.2010.06.001 10.1016/ j.ijedudev.2010.06.001

Todinov, M. (2015). Reliability and risk models. Reliability and risk models: setting reliability requirements.

Xie, I., \& Matusiak, K. (2016). Discover digital libraries. Discover digital libraries: Theory and practice. 